\title{
Technical Note \\ Technological and Environmental Behaviour of Traditional Ceramic Bodies Obtained by Recycling of Two Types of Residues
}

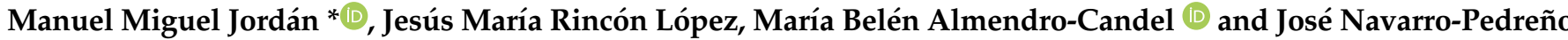 \\ Department of Ago-Chemistry and Environment (GEA-UMH), University Miguel Hernández of Elche, \\ Avda. de la Universidad s/n, 03202 Elche, Alicante, Spain; rinconjma@gmail.com (J.M.R.L.); \\ mb.almendro@umh.es (M.B.A.-C.); jonavar@umh.es (J.N.-P.) \\ * Correspondence: manuel.jordan@umh.es
}

check for

updates

Citation: Jordán, M.M.; Rincón

López, J.M.; Almendro-Candel, M.B.; Navarro-Pedreño, J. Technological and Environmental Behaviour of Traditional Ceramic Bodies Obtained by Recycling of Two Types of Residues. Coatings 2022, 12, 221. https://doi.org/10.3390/ coatings12020221

Academic Editor: Inês Flores-Colen

Received: 14 January 2022

Accepted: 5 February 2022

Published: 8 February 2022

Publisher's Note: MDPI stays neutral with regard to jurisdictional claims in published maps and institutional affiliations.

Copyright: (c) 2022 by the authors. Licensee MDPI, Basel, Switzerland. This article is an open access article distributed under the terms and conditions of the Creative Commons Attribution (CC BY) license (https:// creativecommons.org/licenses/by/ $4.0 /)$.

\begin{abstract}
In this research we evaluated the feasibility of incorporating MSW fly ashes and copper slag in the manufacture of traditional ceramic materials, in addition to assessing the immobilization of $\mathrm{As}$ and $\mathrm{Pb}$ in tiles, linear contraction, bending strength and water absorption (WA), were measured. A decrease in the WA was obtained by increasing the addition of both residues. It is feasible to substitute around $40 \%$ of standard clay for these by-products, with an improvement in the technical specifications of the specimens compared to the ceramic bodies manufactured without adding byproducts. Furthermore, the immobilization of arsenic and lead was tested in the fired bodies. The immobilization of both elements improves as the firing temperature increases, as evidenced by the leaching tests. Regarding the $\mathrm{Pb}$ and As content, all the tested samples comply with established limits for non-hazardous landfill waste (Spanish laws).
\end{abstract}

Keywords: fly ashes; copper slag; ceramic behaviour; leaching tests; recycling wastes

\section{Introduction}

The management and minimization of MSW (municipal solid waste) has become a huge problem at the global level, brought on by the increase in large cities in the world and the growth of industrialization and urbanization. The production of MSW in Spain is up to 21 million tons/year. Around 30\% of these residues are sent to composting plants and around $6 \%$ are intended for incineration [1,2]. Incineration reduces the volume of residue by $90 \%$ but generates new wastes: fly ashes and sludge. The fly ash production is around 25 or $30 \mathrm{~kg}$ per incinerated ton. The fly ashes contain $\mathrm{Al}_{2} \mathrm{O}_{3}, \mathrm{CaO}$ and $\mathrm{SiO}_{2}$ together with metalloids, metals and dangerous organic compounds. The most beneficial protocol would be to transform this waste into a useful and inert raw material for the manufacturing of ceramics [3-5]. Furthermore, pyrometallurgical processes produce a high content of slag [6]. Modern primary smelters generate around $2500 \mathrm{~kg}$ of copper slag (Cu-slag) for $1000 \mathrm{~kg}$ of $\mathrm{Cu}$ generated [6]. Recycling of the cited by-products has environmental and economic benefits. For example, in construction, slags can be used as abrasive material, filler material [7] or in the production of mortars and concretes. Slags with high $\mathrm{SiO}_{2}(9-69 \%)$ and $\mathrm{FeO}(0.6-65 \%)$ content are more common. The presence of $\mathrm{Cu}$, $\mathrm{Zn}, \mathrm{Ni}$ and $\mathrm{Pb}$ and $\mathrm{As}$ in this waste make it an important environmental pollutant [8]. The ceramic industries have great potential to absorb mining, industrial or incineration plant by-products. However, the use of these residues in the manufacture of ceramic bricks is very scarce or non-existent in some European countries.

This work presents the results obtained after replacing a high percentage of clay rich in carbonates and silica with Cu-slag and MSW fly ashes. The aim of this paper is to improve and test some technological properties and to test the immobilization processes of toxic elements ( $\mathrm{As}$ and $\mathrm{Pb}$ ) contained in contaminating wastes at different fired cycles. 
The highlights of this note are (a) to valorise and give new uses to two types of waste that are very harmful to the health of humans, animals and ecosystems and (b) to improve the technological properties of ceramic test bodies made with these residues to enable formulation of compositions on demand to give constructive solutions in the manufacture of bricks, roofing tiles and ceramic flooring and coatings.

\section{Materials and Methods}

Selected MSW fly ash and Cu-slag samples were dried in a laboratory stove at $115^{\circ} \mathrm{C}$ and subsequently ground using a ball mill. The chemical analysis of Cu-slag, fly ash and clay (Table 1) was accomplished by a PW1606 X-florescence (Philips, Eindhoven, The Netherlands) and ICP-MS (PerkinElmer, Glenbrook, CT, USA). The soluble $\mathrm{SO}_{4}{ }^{-2}$ and $\mathrm{Cl}^{-}$ and were analysed by gravimetry and titration, respectively. The $\mathrm{CaCO}_{3}$ percentage was calculated by calcimetry. Total organic matter was measured by calcination at $500{ }^{\circ} \mathrm{C}$. The loss-on-ignition (LOI) was determined at $1000^{\circ} \mathrm{C}$.

Table 1. Chemical composition of ceramic clay, MSW fly ash and copper sludge used in the formulation of compositions.

\begin{tabular}{|c|c|}
\hline \multicolumn{2}{|c|}{ Ceramic Clay } \\
\hline $\mathrm{SiO}_{2}$ & $52.59(\%)$ \\
\hline $\mathrm{Al}_{2} \mathrm{O}_{3}$ & $15.85(\%)$ \\
\hline $\mathrm{Fe}_{2} \mathrm{O}_{3}$ & $5.95(\%)$ \\
\hline $\mathrm{CaO}$ & $12.29(\%)$ \\
\hline $\mathrm{MgO}$ & $1.95(\%)$ \\
\hline $\mathrm{Na}_{2} \mathrm{O}$ & $0.373(\%)$ \\
\hline $\mathrm{K}_{2} \mathrm{O}$ & $5.20(\%)$ \\
\hline $\mathrm{P}_{2} \mathrm{O}_{5}$ & $0.225(\%)$ \\
\hline Total $\mathrm{SO}_{3}$ & $0.650(\%)$ \\
\hline O.M. $500^{\circ} \mathrm{C}$ & $2.00(\%)$ \\
\hline LOI $\left(1000{ }^{\circ} \mathrm{C}\right)$ & $12.20(\%)$ \\
\hline $\mathrm{CaCO}_{3}$ & $26.00(\%)$ \\
\hline $\mathrm{SO}_{4}{ }^{2-}$ (solubles) & 4420 (ppm) \\
\hline $\mathrm{Cl}^{-}$(solubles) & 139.90 (ppm) \\
\hline \multicolumn{2}{|c|}{ MSW Fly Ash } \\
\hline O.M. $500^{\circ} \mathrm{C}$ & $42.50(\%)$ \\
\hline $\mathrm{LOI}\left(1000^{\circ} \mathrm{C}\right)$ & $63.97(\%)$ \\
\hline $\mathrm{CaCO}_{3}$ & $8.96(\%)$ \\
\hline $\mathrm{SO}_{4}{ }^{2-}$ (solubles) & 8055 (ppm) \\
\hline $\mathrm{Cl}^{-}$(solubles) & 739.1 (ppm) \\
\hline $\mathrm{SiO}_{2}$ & $12.55(\%)$ \\
\hline $\mathrm{Al}_{2} \mathrm{O}_{3}$ & $45.30(\%)$ \\
\hline $\mathrm{Fe}$ & $9281(\mathrm{mg} / \mathrm{kg})$ \\
\hline $\mathrm{Ca}$ & $57(\mathrm{mg} / \mathrm{kg})$ \\
\hline $\mathrm{Mg}$ & $43(\mathrm{mg} / \mathrm{kg})$ \\
\hline $\mathrm{Na}$ & $1231(\mathrm{mg} / \mathrm{kg})$ \\
\hline $\mathrm{K}$ & $2325(\mathrm{mg} / \mathrm{kg})$ \\
\hline $\mathrm{P}$ & $32.36(\mathrm{mg} / \mathrm{kg})$ \\
\hline $\mathrm{Cu}$ & $91(\mathrm{mg} / \mathrm{kg})$ \\
\hline $\mathrm{Zn}$ & $166(\mathrm{mg} / \mathrm{kg})$ \\
\hline $\mathrm{Pb}$ & $49(\mathrm{mg} / \mathrm{kg})$ \\
\hline $\mathrm{Hg}$ & $0.25(\mathrm{mg} / \mathrm{kg})$ \\
\hline As & $0.22(\mathrm{mg} / \mathrm{kg})$ \\
\hline $\mathrm{Cd}$ & $3.38(\mathrm{mg} / \mathrm{kg})$ \\
\hline
\end{tabular}


Table 1. Cont.

\begin{tabular}{cc}
\hline \multicolumn{1}{c}{ Cu-Slag } \\
\hline $\mathrm{SiO}_{2}$ & $51.07(\%)$ \\
$\mathrm{Fe}_{2} \mathrm{O}_{3}$ & $17.19(\%)$ \\
$\mathrm{CaO}$ & $18.33(\%)$ \\
$\mathrm{MgO}$ & $1.10(\%)$ \\
$\mathrm{K}_{2} \mathrm{O}$ & $2.19(\%)$ \\
$\mathrm{CuO}$ & $0.92(\%)$ \\
$\mathrm{SO}_{3}$ & $0.15(\%)$ \\
$\mathrm{Al}_{2} \mathrm{O}_{3}$ & $8.95(\%)$ \\
$\mathrm{Zn}$ & $0.20(\%)$ \\
$\mathrm{Co}_{3} \mathrm{O}_{4}$ & $0.08(\%)$ \\
$\mathrm{PbO}^{\mathrm{As}} \mathrm{O}_{3}$ & $0.31(\%)$ \\
$\mathrm{LOI}$ & $0.49(\%)$ \\
\hline
\end{tabular}

The mineralogical characterization of the selected clay was determined by $\mathrm{X}$-ray diffraction $(\mathrm{Cu}-\mathrm{K} \alpha$ radiation $50 \mathrm{kV}, 30 \mathrm{~mA})$ using a Siemens device (Siemens D5000D, Berlin, Germany). Different treatments were prepared for clay minerals analysis. Mixtures and firing cycles were design based on previous own experiences and revised literature [3,4] Experimental tests were performed on several mixtures of clay + MSW fly ash $+\mathrm{Cu}$-slag. The formulations for ceramic tests consisted of the following compositions with $\mathrm{Cu}$-slag: 0 (control), 15, 20, 25, 30 and 35\% (wt.\%), and MSW fly ash waste: 0 (control), 1, 2, 3, 4, 5 and 10 (wt.\%). The first step was drying for $24 \mathrm{~h}$ at room temperature and the second stage was oven drying to $105^{\circ} \mathrm{C}$ (heating speed: $8^{\circ} \mathrm{C} / \mathrm{h}$ ). This two-stage process is commonly used in the brick and ceramic tile industry. In stage 1 the drying rate is rapid and constant as water evaporates from the surface into the surrounding air and water from the interior migrates by capillary action to the surface to replace it. In stage 2 the moisture content is reduced to where the ceramic grains are in contact. The green test bodies (unfired) were pressed using a uniaxial press. A firing cycle was designed (Troom-500 ${ }^{\circ} \mathrm{C}: 2 \mathrm{~h} ; 500-650^{\circ} \mathrm{C}: 2 \mathrm{~h}$; 650-Tmax: 2 h; Tmax: 900, 950, 1000 and $1050^{\circ} \mathrm{C}$ over $4 \mathrm{~h}$ following normal European industrial practice. Figure 1 shows the aspect of test bodied fired at different temperatures $\left(900,950,1000\right.$ and $\left.1050{ }^{\circ} \mathrm{C}\right)$.

The linear contraction was tested following the methodology described in $[4,9]$ for dried (D.L.C.) and heated (H.L.C.) tiles. The WA (\%) has measured following UNE-EN ISO 10545-3:2018 [10]. Bending or Flexural strength ( $\sigma \mathrm{f})$ was tested using an INSTRON 1011. All determinations were carried out in triplicate. Studied residues contain significant amounts of pollutants, mainly $\mathrm{Pb}$ and As. The mobility of a toxic element defines its dangerousness. Therefore, a test of $\mathrm{pH}$ dependence was carried out. For the powder mixtures tested, the initial $\mathrm{pH}$ value was up to $9 . \mathrm{HNO}_{3}(5 \mathrm{~mol} / \mathrm{L})$ was added to reduce $\mathrm{pH}$. The significant content of $\mathrm{CaCO}_{3}$ present in both fly ash $(7 \%)$ and clay $(>22 \%)$ neutralizes this chemical reaction, and $\mathrm{Ca}\left(\mathrm{NO}_{3}\right)_{2}$ is formed. Dangerous and toxic elements leaching were evaluated using the equilibrium leaching tests following the UNE-ENVI 12506: 2001 [11]. Samples were sieved (particle size of at least $95 \%$ (mass) $<10 \mathrm{~mm}$ ) and dried at a temperature $<40{ }^{\circ} \mathrm{C}$. These samples were placed in polyethylene bottles together with water (liquid $/$ solid ratio $=10 \mathrm{~L} / \mathrm{kg}$ ). A shaking device was used to shake the bottles for $24 \mathrm{~h}$. Finally, solid particles were allowed to settle for $15 \mathrm{~min}$ and the eluate was filtered through $0.45 \mu \mathrm{m}$ membrane filters in a vacuum device. ICP-MS determinations were carried out with matrix-matched standards. The recovery values of the elements were quantified, and the relative standard deviations were calculated. 


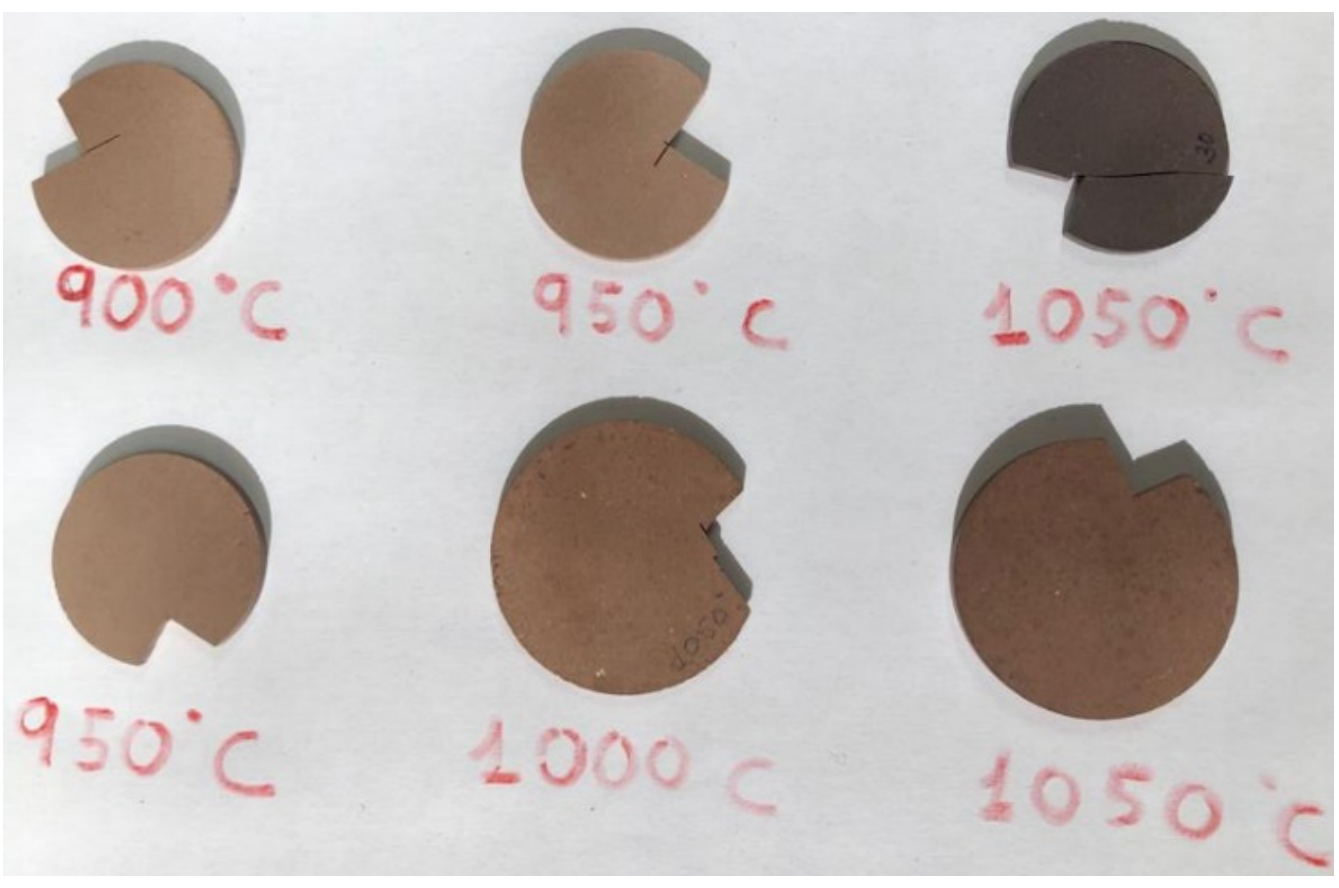

Figure 1. Test bodies fired at different temperatures.

\section{Results and Discussion}

The selected clay, which is rich in $\mathrm{SiO}_{2}$ and $\mathrm{CaCO}_{3}$ with an appreciable $\mathrm{Fe}_{2} \mathrm{O}_{3}$ content gives rise, after firing, to red pastes. The main mineral phases present were quartz, hematite, clay minerals (illite, chlorite and kaolinite) and low quantities of dolomite, feldspar and calcite. Fly ash comes from MSWI having mixture of crystalline and amorphous phases; mostly amorphousness is higher than $50 \%$, composed of aluminous silicate with silicate material and sulphates. The selected MSW fly ashes have low values of $\mathrm{Pb}, \mathrm{Cu}, \mathrm{Zn}$, and $\mathrm{Hg}$ compared to the contents reported in the literature [1,2]. The mineralogy of the selected fly ash was: quartz $\left(\mathrm{SiO}_{2}\right)$, silvine $(\mathrm{KCl})$, anhydrite $\left(\mathrm{CaSO}_{4}\right)$, fluorite $\left(\mathrm{Ca}(\mathrm{OH})_{2}\right), \mathrm{CaClOH}$ and halite $(\mathrm{NaCl})$. XRD patterns of clay, MSW fly ash and Cu-slag can be found in an article publish previously [12]. Copper slag is predominantly composed of $\mathrm{SiO}_{2}(>50 \%), \mathrm{Fe}_{2} \mathrm{O}_{3}(>17 \%)$, $\mathrm{CaO}(>15 \%), \mathrm{Al}_{2} \mathrm{O}_{3}(>8), \mathrm{K}_{2} \mathrm{O}(>2 \%)$ and $\mathrm{MgO}(1 \%) . \mathrm{ZnO}$ and $\mathrm{CuO}$ are present in percentages less than $1 \%$. However, $\mathrm{Pb}$ and $\mathrm{As}$ are considered environmental pollutants. The chemical composition of the analysed $\mathrm{Cu}$-slag is different to other standard slags. The standard massive $\mathrm{Cu}$-slag has a chemical composition dominated by $\mathrm{FeO}(>52 \mathrm{wt} . \%), \mathrm{SiO}_{2}(>45 \mathrm{wt} . \%)$ and $\mathrm{Al}_{2} \mathrm{O}_{3}(>12 \mathrm{wt} . \%)$. It comprises two types of silicate glass, olivine, ferrosilite, fayalite, cristobalite and quartz. The mineralogy of the selected $\mathrm{Cu}$-slag is defined by the presence of cristobalite $\left(\mathrm{SiO}_{2}\right)$, clinoferrosilite $\left(\mathrm{FeSiO}_{3}\right)$, magnetite $\left(\mathrm{Fe}_{2} \mathrm{O}_{4}\right)$ and fayalite $\left(\mathrm{Fe}_{2} \mathrm{SiO}_{4}\right)$. Traces of wollastonite $\left(\mathrm{CaSiO}_{3}\right)$ and feldspar as microcline $\left(\mathrm{KAlSi}_{3} \mathrm{O}_{8}\right)$ were also found.

Figure 2a shows the evolution of values of linear contraction for the control and for the rest of the mixtures tested, which were in the normal range $(<10 \%)$. Figure $2 \mathrm{~b}$ shows a clear tendency to a reduction in open porosity when the content of added by-products increases. Consulting the UNE 136020: 2004. CTN 136- Clay products for construction [13], technicians can find specifications that must be met by construction materials, which opens a great versatility of choice of raw materials and by-products to reach the required standards. 


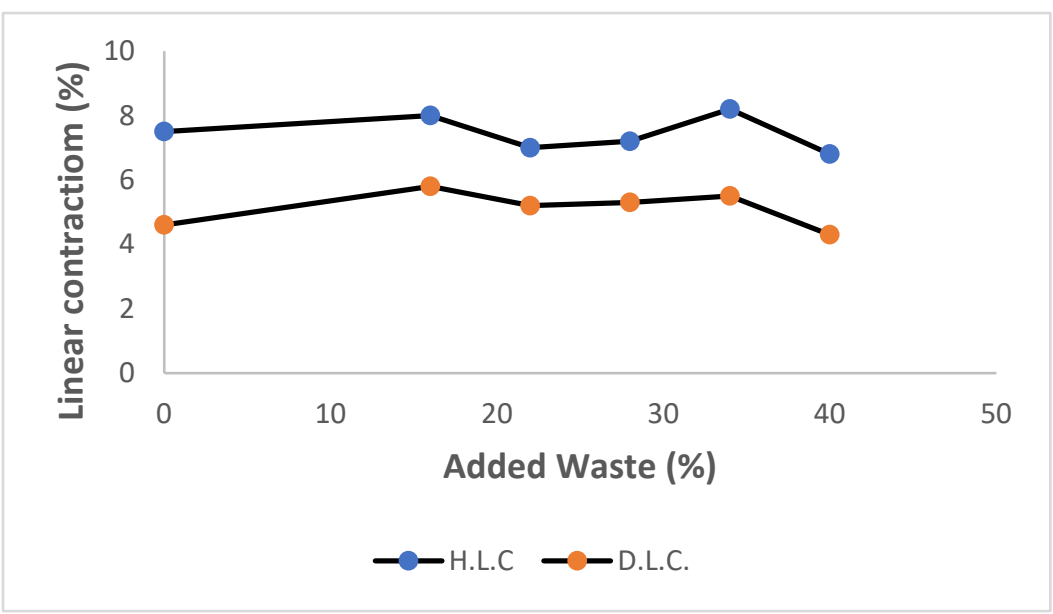

(a)

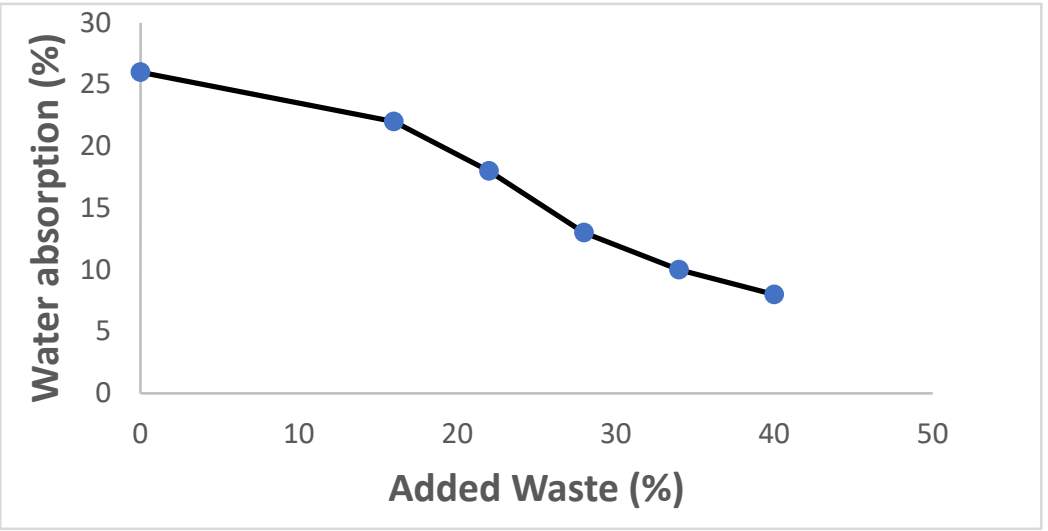

(b)

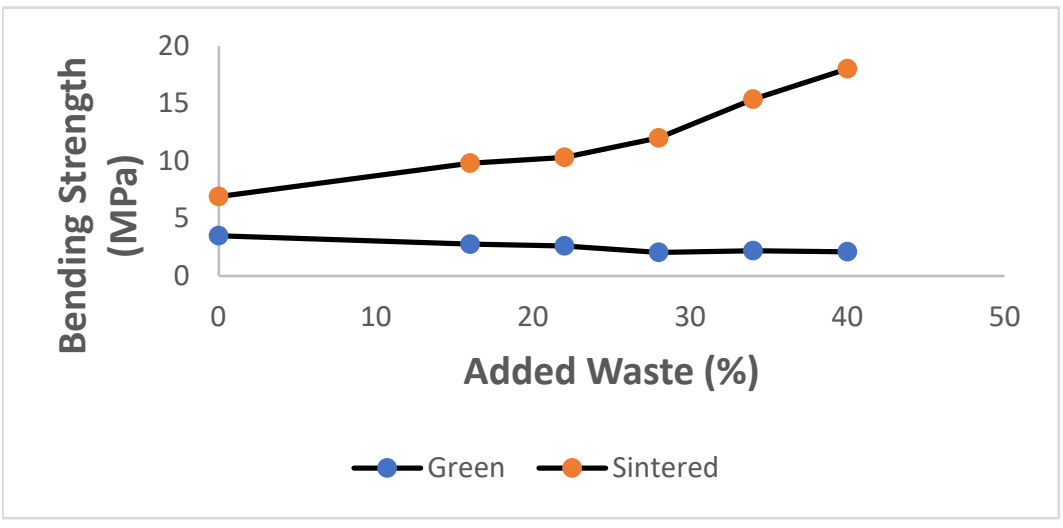

(c)

Figure 2. Technological properties for (a) LC at $1050{ }^{\circ} \mathrm{C}(\%),(b) \mathrm{WA}(\%)$ at $1050{ }^{\circ} \mathrm{C}$ and (c) bending/flexural strength at $1050^{\circ} \mathrm{C}$. Legend: Green-unfired tiles; Sintered-fired tiles.

With the introduction of $3 \%$ MSW fly ash $+25 \%$ of Cu-slag ( $28 \%$ wastes $+12 \%$ clay), the WA value was around $13.2 \%$. This is a good value for structural ceramic materials used in building $[13,14]$. The addition of these residues makes it possible to obtain structural ceramic materials, which was impossible using only clayey raw materials with a moderate or high content of carbonates [13].

The incorporation of these residues makes it possible to achieve much lower WA values at a similar firing temperature, contributing considerably to the reduction in energy costs and greenhouse gas emissions [5]. The addition of wastes improves flexural strength (Figure 2c). With a proper management in the incorporation of selected wastes, following 
the specific materials' international regulations, it is possible to manufacture different types of building materials [5].

Currently with the selected clay it is possible to manufacture non-structural ceramics (e.g., ceramic tiles, pavements and ceramic coatings). With the addition of selected mixture of wastes, the water absorption capacity (WA) and mechanical resistance (bending strength) were significantly improved. However, the additional advantage is that with the addition of $28 \%$ of by-products it is feasible to obtain structural ceramics (e.g., solid brick blocks) complying with the technical specifications regulated in the technical code for building materials.

Table 2 shows the test bodies and discharge limit regulations for $\mathrm{As}$ and $\mathrm{Pb}$ together with $\mathrm{Co}, \mathrm{Cd}$ and $\mathrm{Zn}$ leachate amounts for all firing cycles and formulations tested. All regulations for building-residue landfills have been consulted, taking into consideration the future destination of eco-materials produced using toxic residues at the end of their life cycle. All materials tested comply with the current regulations for disposal in landfills (non-hazardous waste) regarding the $\mathrm{Pb}$ and As contents. Arsenic and lead have been immobilized in ceramic bodies fired at temperatures of 1000 and $1050{ }^{\circ} \mathrm{C}$. The behaviour of the fired bodies fits well within regulations for their disposal in inert-residue landfills. No clear results were observed in other metals $\left({ }^{*} \mathrm{Co},{ }^{*} \mathrm{Cd},{ }^{* *} \mathrm{Cu}\right.$ and ${ }^{*} \mathrm{Zn},{ }^{*}$ Leachates conc. of $\mathrm{Cd}, \mathrm{Zn}$ and $\mathrm{Co}:<0.02 \mathrm{mg} / \mathrm{L}$, ${ }^{* *}$ Leachates conc. of $\mathrm{Cu}:<0.10 \mathrm{mg} / \mathrm{L}$.), due to their low concentrations in solution. Different studies have demonstrated that leachate $\mathrm{pH}$ is a determinant of the solubility of some elements [8]. Probably, in the As and $\mathrm{Pb}$ immobilization process the role played by $\mathrm{CaO}$ present in clay and ashes is a determinant of their inertisation [8].

Table 2. Arsenic (As) and lead $(\mathrm{Pb})$ levels $(\mathrm{mg} / \mathrm{kg})$ in tests and discharge limits regulated in Spain (BOE, number 97, 23 April 2013, Ministerial Order AAA/661/2013). Legend: W (control, 0\%); A ( $16 \%), \mathrm{B}(22 \%), \mathrm{C}(28 \%), \mathrm{D}(34 \%)$ and $\mathrm{E}(40 \%)$.

\begin{tabular}{cccc}
\hline $\begin{array}{c}\text { Tmax: } \mathbf{9 0 0}{ }^{\circ} \mathbf{C} \\
\text { Added By-Products (\%) }\end{array}$ & As & Pb & pH Values \\
\hline W & $0.1 \pm 0.05$ & $0.08 \pm 0.02$ & $7.8 \pm 0.2$ \\
A & $0.59 \pm 0.02$ & $0.09 \pm 0.02$ & $7.7 \pm 0.2$ \\
B & $0.73 \pm 0.03$ & $0.46 \pm 0.01$ & $7.9 \pm 0.1$ \\
C & $0.79 \pm 0.01$ & $0.65 \pm 0.03$ & $8.1 \pm 0.2$ \\
D & $1.2 \pm 0.02$ & $0.73 \pm 0.01$ & $8.5 \pm 0.3$ \\
E & $1.3 \pm 0.05$ & $0.81 \pm 0.04$ & $8.7 \pm 0.2$ \\
Tmax: 950 ${ }^{\circ} \mathbf{C}$ & & & \\
W & $0.21 \pm 0.06$ & $0.06 \pm 0.02$ & $7.5 \pm 0.3$ \\
A & $0.35 \pm 0.05$ & $0.09 \pm 0.01$ & $7.6 \pm 0.4$ \\
B & $0.51 \pm 0.03$ & $0.33 \pm 0.03$ & $7.8 \pm 0.1$ \\
C & $0.62 \pm 0.02$ & $0.52 \pm 0.02$ & $8.1 \pm 0.3$ \\
D & $0.82 \pm 0.03$ & $0.63 \pm 0.01$ & $8.2 \pm 0.1$ \\
E & $0.93 \pm 0.06$ & $0.72 \pm 0.04$ & $8.3 \pm 0.2$ \\
Tmax: 1000 ${ }^{\circ} \mathbf{C}$ & & & \\
W & $0.11 \pm 0.02$ & $<0.05$ & $7.4 \pm 0.2$ \\
A & $0.14 \pm 0.04$ & $<0.05$ & $7.5 \pm 0.1$ \\
B & $0.23 \pm 0.02$ & $<0.05$ & $7.7 \pm 0.1$ \\
C & $0.34 \pm 0.04$ & $<0.05$ & $7.8 \pm 0.2$ \\
D & $0.43 \pm 0.01$ & $<0.05$ & $8.1 \pm 0.1$ \\
E & $0.49 \pm 0.05$ & $<0.05$ & $8.2 \pm 0.3$ \\
Tmax: 1050 ${ }^{\circ} \mathbf{C}$ & & & \\
W & $0.04 \pm 0.01$ & $<0.05$ & $7.2 \pm 0.1$ \\
A & $0.12 \pm 0.02$ & $<0.05$ & $7.4 \pm 0.2$ \\
B & $0.13 \pm 0.02$ & $<0.05$ & $7.6 \pm 0.3$ \\
C & $0.19 \pm 0.01$ & $<0.05$ & $7.8 \pm 0.2$ \\
D & $0.23 \pm 0.03$ & $<0.05$ & $7.9 \pm 0.1$ \\
E & $0.39 \pm 0.04$ & $<0.05$ & $7.8 \pm 0.2$ \\
\hline & & &
\end{tabular}


Table 2. Cont.

\begin{tabular}{cccc}
\hline $\begin{array}{c}\text { Tmax: } 900{ }^{\circ} \mathbf{C} \\
\text { Added By-Products (\%) }\end{array}$ & As & $\mathbf{P b}$ & pH Values \\
\hline $\begin{array}{c}\text { Inert wastes landfill } \\
\begin{array}{c}\text { Non-hazardous wastes } \\
\text { ladfill }\end{array}\end{array}$ & 0.5 & 0.5 & Limits regulated \\
\hline
\end{tabular}

\section{Conclusions}

The addition of Cu-slag and MSW fly ashes makes it possible to obtain improved performance in the manufacture of structural ceramics. $\mathrm{Pb}$ and As were immobilized during the firing process in bodies fired at 1000 and $1050{ }^{\circ} \mathrm{C}(\mathrm{A}, \mathrm{B}, \mathrm{C}$, and $\mathrm{E}$ mixtures). The ceramic industry has great potential to absorb by-products. However, the use of these residues in the manufacture of ceramic bricks, roofing tiles and ceramic flooring and coatings is very scarce or non-existent in some European and other countries. The addition of this kind of residue improves the technological properties giving rise to a wide range of available building materials with higher added value using the same industrial firing cycles $[13,14]$. Another advantage is that with the addition of selected by-product mixtures, it is feasible to obtain solid brick blocks. The last step of this research is working with industrial-sized ceramic bodies. It will be necessary to carry out a proof of concept together with the ceramic industry in a pilot plan. This would be the last step in bringing this experimental product to market. It is necessary to create a culture of waste recycling in the industry as well as to promote the commitment to the circular economy and responsible consumption.

Author Contributions: Conceptualization, M.M.J. and J.M.R.L.; investigation, M.B.A.-C. and J.N.-P.; methodology, M.B.A.-C. and J.N.-P.; data curation, M.M.J. and J.M.R.L.; writing-original draft preparation, M.M.J.; writing—review and editing, M.M.J.; supervision, J.M.R.L. and M.M.J. All authors have read and agreed to the published version of the manuscript.

Funding: This research received no external funding.

Institutional Review Board Statement: Not applicable.

Informed Consent Statement: Not applicable.

Data Availability Statement: All data, are included in the submitted manuscript.

Conflicts of Interest: Authors declare no conflict of interest.

\section{References}

1. Tayibi, H.; Peña, C.; López, F.A.; López-Delgado, A. Management of MSW in Spain and recovery of packaging steel scrap. Waste Manag. 2006, 27, 1655-1665. [CrossRef] [PubMed]

2. Costi, P.; Minciardi, R.; Robba, M.; Rovatti, M.; Sacile, R. An environmentally sustainable decision model for urban solid waste management. Waste Manag. 2004, 24, 277-295. [CrossRef]

3. Hernández-Crespo, M.S.; Rincón, J.M. New porcelainized stoneware obtained by recycling of MSW incinerator fly ashes and granite sawing residues. Ceram. Int. 2001, 27, 713-720. [CrossRef]

4. Montero, M.A.; Jordán, M.M.; Hernández, M.S.; Sanfeliu, T. The use of sewage sludge and marble residues in the manufacture of ceramic tile bodies. Appl. Clay Sci. 2009, 46, 404-408. [CrossRef]

5. Zhang, L. Production of bricks from waste materials: A review. Constr. Build. Mater. 2013, 4, 643-655. [CrossRef]

6. Nazer, A.; Payá, J.; Borrachero, M.V.; Monzó, J. Caracterización de escorias de cobre en fundiciones chilenas. Rev. Metal. 2016, 52, e083. [CrossRef]

7. Murari, K.; Sissique, R.; Jain, K.K. Use of copper slag. A sustainable material. J. Mater. Cycles Wastes 2015, 17, 13-26. [CrossRef]

8. Piatak, N.M.; Parsons, M.B.; Seal, R.R., II. Characteristics and environmental aspects of slag: A review. Apply. Geochem. 2015, 57, 236-266. [CrossRef]

9. Díaz, M.; Plaza, P.; Blanco, D.; Jordán, M.M.; Sáez del Bosque, I.F.; Medina, C. The design and development of recycled concretes in a circular economy using mixed construction and demolition waste. Materials 2021, 14, 4762.

10. ISO 10545-3:2018; Ceramic Tiles-Part 3: Determination of Water Absorption. ISO: Geneva, Switzerland, 2018.

11. UNE-ENV 12506:2001; Characterization of Waste. Analysis of Eluates. Determination of pH, Cd, As, Cr (VI), Cu, Zn, Pb, Ni, $\mathrm{SO}_{4}{ }^{2-}, \mathrm{NO}^{-}$and $\mathrm{Cl}^{-}$. UNE: Madrid, Spain, 2001. 
12. Jordán, M.M.; Montero, M.A.; Pardo, F. Technological behavior and leaching tests in ceramic tile bodies obtained by recycling of copper slag and MSW fly ashes. J. Mater. Cycles Waste Manag. 2021, 23, 707-716. [CrossRef]

13. UNE 136020:2004; CTN 136-Clay Products for Construction. UNE: Madrid, Spain, 2004.

14. UNE-EN 538:1995; Clay Roofing Tiles for Discontinuous Laying_Flexural Strength Test. UNE: Madrid, Spain, 1995. 